\title{
The effect of Managerial Ability towards Earning Quality with Audit Committee as Moderating Variable
}

\author{
SeTin SeTin \\ Universitas Kristen Maranatha, Bandung, Indonesia \\ Etty Murwaningsari \\ Universitas Trisakti, Jakarta, Indonesia
}

\author{
Keywords \\ Managerial Ability, Audit Committee, Earnings Quality
}

\begin{abstract}
The purpose of this research is to examine the effect of managerial ability towards earnings quality with audit committee as the moderation variable. The research data is secondary data, which is data from the audited financial statements of 53 go public manufacturing companies in Indonesia with 159 units of analysis for the period of 2014-2016. Data is obtained from the Indonesian Capital Market Directory. The results show that (i) managerial ability has a positive and significant effect towards the earnings quality; (ii) The macro condition represented by the interest rate has a negative and insignificant effect towards earnings quality; (iii) The audit committee strengthens the effect of managerial ability towards earnings quality. This research contributes to enrich the earnings quality literature, especially about the role of managers, which is managers are not the absolute profit management actors, but capable managers create efficiency and improve earnings quality.
\end{abstract}

Corresponding author: SeTin SeTin

Email addresses for corresponding author: setin2005@yahoo.com

First submission received: $3^{\text {rd }}$ September 2017

Revised submission received: 3 rd October 2017

Accepted: 15 th November 2017

\section{Introduction}

Research about earnings quality continues to grow rapidly in the last two decades (Defond, 2010). One of the factors that drives the development of earnings quality research is the strong allegation of managers are the actors of earnings management. This allegation is proved by several studies like Healy, 1996; Houlthausen et al., 1995; Healy, 1985; Velury \& Jenkins, 2006; Francis et al, 2008. However, there are also several researches that show different results, one of them is the quality of earnings is positively associated with managerial skills (Demerjian et al 2012, 2013). Demerjian et al (2013) explains that a manager with a good managerial skills will be able to use company resources more efficiently and eventually will be able to report earnings with higher-quality. The results of this research are in common with the opinion of Dechow and Schrand (2004) which is, that the high-quality profit accurately reflects the operational performance of the company. In other words, if the quality of profit is higher, the company's performance is also higher (Machdar et al, 2017).

Previous researches have shown that managers are the main actors of earnings management practices that would disrupt the earnings quality. Healy (1996) explains that managers perform earnings management to improve the welfare of investors by lowering taxes or reducing regulatory costs. Houlthausen et al (1995) showed that managers manipulate earnings to maximize the present value of bonus payments. Healy (1985) also found that managers make use of discretionary accruals to increase the compensation they wish to receive. Prior to Demerjian et al's research $(2012,2013)$, capable managers were considered to have understood with the company's business conditions and were able to see the accrual component to maximize their bonuses. Managers are always considered to behave opportunistically and are able to take advantage of existing opportunities (the flexibility of accounting standards with various method options) to perform earnings management. Profit management practices lead to lower reported earnings quality (Velury and Jenkins, 2006) 
The results from Demerjian et al's research $(2012,2013)$ provide a new description of a capable manager. A capable manager will produce a much higher output-input ratio, than managers with lower managerial skills. Capable managers have the abality to implement superior business systems and efficient processes such as supply chains and compensation systems. Good managers can also estimate more accurate accruals for the environment and conditions which the company is facing.

The results from Demerjian et al's research $(2012,2013)$ also emphasized the results of Aier et al's (2005) research which noted the relationship between CFO expertise (working for years as CFO, other experience in the company, advanced degree, and professional certification) by restatement of financial statements and concluded that companies that employ $\mathrm{CFO}$ with greater expertise, would have fewer (smaller) earnings restatements.

Although there is some evidence that more capable managers have positive effect towards earnings quality, Francis et al (2008) notes that more capable managers correspond to lower earnings quality. This finding is consistent with some of the less predictable companies related to the income and their business behaviour resulting in lower earnings quality (Dechow and Schrand 2004; Lafond 2008). Francis et al (2008) also emphazied the results of previous researches that relate managerial capabilities with earnings management practices that reduce earnings quality.

Since there is still a contradiction between previous research results when it comes to the relationship between managerial ability and earnings quality, we decided to conduct a further research of this variable, with an aim to reconcile and provide a new perspective of previous research results.

To date, most of the literature on earnings quality has examined a number of company-specific characteristics that may affect earnings quality. It is possible that the variation in earnings quality is driven by the inherent characteristics of the company that cannot be effected by managers and certainly we will not find the relation between managerial ability and earnings quality. However, besides the inherent characteristics, the earnings quality is also related to the company's infrastructure, such as the internal controls quality (Doyle et al 2007; Ashbaugh-Skaife et al 2008) and monitoring, for example by auditors (Becker et al 1998). Demerijan et al (2013) also explains that there are many factors related to earnings quality, such as company and industry size, operating cycle, purpose of corporate strategic and corporate competitive advantage. Dechow and Dichev (2002) show that earnings quality will be worse for smaller companies and will experience in loss.

Of the many company characteristics related to earnings quality, this research continues the suggestion of Demerjian et al (2013) to examine the relation between internal control ability and earnings quality. The reason is that internal control is an infrastructure that has been proven to be able to realize the company's goals. The effectiveness of the company's internal control is determined by the four elements of the control environment, namely the philosophy and style of operation, the functioning of the board of commissioners and the audit committee, management control methods and control awareness. Of the four elements of this control environment, this research focuses on the audit committee. Barako et al, 2007 explains that the audit committee provides a supervisory mechanism that can improve the quality of information among owners and managers, especially in financial reporting that allows variation in information disclosure. The board of directors with the help of audit committee will be responsible of examining corporate financial information for the benefit of stakeholders (Murwaningsari, 2014). The existence of an audit committee within the company as a form of good corporate governance implementation is expected to ensure financial statements that describe real information about the company's operations so as to strengthen the effect of managerial ability in improving earnings quality.

Besides the managerial capabilities and internal control capabilities, this research also developed Demerjian's et al (2013) research by examining the effect of macro conditions on earnings quality. Besides the internal factors, macroeconomic conditions as an external factor can also affect the financial performance of the company. Some macroeconomic variables, such as high interest rates, high inflation rates and high exchange rate fluctuations, are believed by many researchers that these macro variables can cause companies to experience financial difficulties that can reduce their financial performance, resulting in an impact on earnings quality (Charitou et al. 2004, Pareira, 2010).

The purpose of this research is to examine the effect of managerial ability towards earnings quality with audit committee as a moderation variable. This research contributes to the literature on 
earnings quality, namely that managerial ability can be an important factor in improving the earnings quality and internal controls to strengthen the effect of managerial ability towards earnings quality.

\section{Literature Review and Hypothesis Managerial Ability and Earnings Quality}

The ability of managers in designing efficient business processes and being able to make valueadded decisions is the key to corporate success. Efficient business processes can be seen from the use of input and output produced by the company. Managers are obliged to communicate the company's performance as reflected in the financial statements to stakeholders. Preparation of financial statements are expected to provide information to investors and creditors in decisions-making related to the investment which will be done. Judgment managers in the process of preparing financial statements are required to improve the value of corporate accounting. Healy and Wahlen (1999) provide examples of judgment managers in the financial statements, such as estimating incidents containing future economic value like estimated economic life and residual value of long-term assets. Managers are also free to choose a set of accounting methods that are allowed to report the same economic transactions as the use of straight-line method or acceleration method in depreciation recording, or choose average or FIFO in inventory valuation. Managers must also choose to suspend expenses such as research and development $(\mathrm{R} \& \mathrm{D})$. Managers are required to have sufficient skills to be able to perform good judgment. The manager's expertise in judgment is enabled because the manager has an adequate level of education and experience.

Demerjian et al (2006) examines the effect of managerial skill in finance towards the earnings quality that is to examine how efficient a company in finance relative towards other company in the same industry. Demerjian et al (2006) found a positive effect between managerial skills and earnings quality. In other words, the more capable a manager, the higher the resulting profits. The manager is said to be capable if the manager has adequate expertise (education and experience) in the field of responsibility. The more experienced a manager, the more the manager's understanding of the company's business conditions. The manager in performing his duties is also guided by codes of conduct or codes of ethics, so that every manager's decision reflects the manager's professional judgment, not implement decisions which aimed at self-benefit. Every manager's decision will eventually have an impact on the company they lead, that is, corporate level decision-making reflects the level of competence of different managers.

The earnings quality is an important characteristic of financial statements that affects the efficiency of resource allocation. The information contained in the earnings is the key indicator that is used by investors and analysts to assess the company's performance and decision making. Companies with poor earnings quality tend to require higher capital costs (Francis et al., 2004) and tend to restate the financial statements. Companies with good earnings quality reflect the good performance of the the operations (Dechow and Schrand, 2004). The operational performance of the company can not be separated from the main actor that is the manager. Bamber et al (2010) found that each manager has a "special style" relating to their tendency to set policy. The same opinion is showed by Ge et al. (2011) and DeJong and Ling (2010) who examined the effect of managers on financial reporting policies and the results are the same as Bamber et al (2010), namely that accounting policies and company disclosure policies are highly determined / effected by the managers (fixed) who have worked long enough in the company.

High capability managers are able to find out more about the company and industry, and able to synthesize information that can be reliably predicted in the future (Libby and Luft 1993). Demerjian et al (2013) explains that higher capability managers will more accurately estimate the accruals than expected by managers with lower capability. For example, the estimated allowance for bad debts. Lower capability managers may apply only historical rates for bad debts to companies, but higher capability managers may be able to adjust historical rates by considering macro-economic and industrial trends, as well as changes in the company's customer base.

This research assumes the ability of managers to provide accurate assessments and accurate estimations for various purposes. The research also suggests that higher-capability managers can report more accurate levels of fair value, justifiable depreciation rates and other accrual estimates. By assuming the company is in stable conditions, it is expected that capable managers will be more capable to predict 
trends as well as in assessing and estimating accruals, and eventually companies will be able to show good earnings quality.

\section{H1: Managerial ability has a positive effect towards earnings quality Macroeconomic Conditions and Earnings Quality}

Macroeconomic explains the economic changes that affect the community, companies, and markets. One of the key of company's success depends on the economic environment (macroeconomic conditions). Macroeconomic conditions provide a reflection of the overall economy and can affect performance and business value. Macro economic factors are variables that cannot be measured directly, therefore, inflation rate, interest rates and economic growth are used as a reflect of macroeconomic factors. Stability of macroeconomic conditions become the external factors besides the internal factors (managerial capabilities and internal control capabilities) are predicted to have effect towards earnings quality. Many researchers believe that some macroeconomic variables, such as high interest rates (Charitou et al., 2004), high inflation rates (Pareira, 2010) have caused companies to experience financial difficulties that can degrade financial performance and in earnings quality.

\section{H2: Macroeconomic Conditions have a positive effect towards earnings quality Audit Committee, Managerial Ability and Earnings Quality}

Internal control by Arens and Loebbecke (2008) is a process that is effected by board of commissioners, management, and other business unit personnel (internal auditors) which is designed to gain adequate confidence related to the achievement of objectives. The Committee of the sponsoring organizations of the Treadway Commission (COSO) defines internal control as a process which is run by board of commissioners, management and other personnel (internal auditors) which is designed to provide assurance regarding the reliability of financial reporting, effectiveness and efficiency of operations, and abide by the laws and regulations. Seeing that the effectiveness of internal controls often depends on competencies that include the expertise, knowledge, and experience of the internal auditor, the competence of the internal auditor becomes an important factor that describes the company's internal control capabilities.

Considering each manager has their private concerns, it will be naïve to expect a manager to always report quality earnings. To increase the earnings quality, by restricting earnings management behavior, some control mechanism towards the management behaviour is needed which is known as corporate governance. Babatunde and Olaniran (2009) state that corporate governance mechanism can be done using an internal mechanism which involves the board of commissioners assisted by audit committee. Audit committee is the independent party who is assigned to supervise the process of financial reporting (Murwaningsari, 2014) and has independent and competent qualifications in the field of accounting and finance (Bapepam no.Kep-29/PM/2004). Therefore, the role of the audit committee will affect the earnings quality of the company. This result is in commo with Dechow et al. (1995) who states that the company internal structure, which consisted of the role of the board of commissioners' control, is a factor that limits manager's ability and chance to modify earnings.

\section{H3: Audit committee will strengthen the effect of managerial ability towards earnings quality} Firm Size, Abnormal Return, Leverage, Liquidity and Capital Structure

Brigham and Houston, 2001 explain that firm size is a scale which can be classified according to the revenue size, total assets, and total equity. Jang et al. (2007) suggest that how firm size has a positive effect towards earnings response coefficients (as a measuring tool for earnings quality). Dechow and Dichev (2002) show that the quality of earnings will be worse for smaller companies and will experience loss. Therefore, firm size will have a postitive effect towards earnings quality. According to Jogiyanto (2010), abnormal return is the excess of actual return compared to the normal return. Normal return is the expected return or the returns expected by investors. Thus the abnormal return is the difference between the actual return and the expected return. Brown and Warner (1985) in Jogiyanto (2005:43-49) estimate the expected return using the mean-adjusted model, market model, and market adjusted model. The market reaction is shown by the changes in the company's stock prices as measured by abnormal return. The announcement which contained the information will provide an abnormal return. Announcement that contains information will provide abnormal return to the market. On the other 
hand, the announcement that does not contain the information will not provide an abnormal return to the market. This situation will affect the reaction/response of the investors, and if the response is good, then the earnings quality is also expected to be good. This research uses the market adjusted model to assess abnormal return because it was considered that the best estimator for estimating the return of a security is the market index return at that time. Therefore, Abnormal return is has a positive effect towards earnings quality.

Leverage ratio is the comparison between total of debt and total of capital. A low leverage value indicated a better ability for the company to pay the debt using the total funds owned by the company (Copeland T.E dan J.F. Weston, 1992). Company debt is related to the advantage that will be acquired by the company (Keshtavar et al., 2013). The higher the debt, the company will be more dynamic. Management will be encouraged to improve their performance so that loans will be fulfilled, so that the positive effect is that the company will develop. Therefore, the leverage ratio will have a positive effect towards earnings quality.

Capital structure is a permanent expenditure which reflects a balance between the long-term debt and capital owned by the company (Murwaningsari, 2014). The increment of debt will provide benefits related to tax payments and will be able to increase the profits of shares received by a shareholder, so that the ultimate goal of a company to maximize the prosperity of shareholders will be achieved (Modigliani and Miller, 1958). Therefore, capital structure will have a positive effect towards earnings quality. Liquidity is the ability of companies to fulfill short-term debt to current assets owned. The increment of liquidity is due to information asymmetry (Ammihud, 2008). Gharezi and Zadeh (2013) state that liquidity has a weak and negative effect towards earnings quality. Therefore, liquidity will have a negative effect towards earnings quality.

\section{Research Methodology Sample selection}

The research population is all manufacturing companies listed on Indonesia Stock Exchange for the period of 2014-2016. The manufacturing industry is chosen because it has many listing companies with various data. The reason of using period of 2014-2016 is that the data of these three years are available and can be accessed by public, and also able to describe the most recent profile of financial information of 104 companies in the manufacturing industry. A total of 53 companies (159 observation) can be analyzed.

\section{Variables and Measurement}

Earnings quality used for this research is Velury's (1999) measurement, which measures the earnings quality in accordance with (SFAC No. 2), namely the predictive value measured by the persistence of earnings (the percentage change in previous year's sales minus the percentage change in gross profit of the previous year). The research sees at the signal indicated by the percentage change previous year's sales minus the percentage change in gross profit of the previous year. If the signal indicates a positive change is given a value of 1 , and if the signal indicates a negative change is given a value of 0 .

Managerial ability is measured using the same measure tool used by Demerjian et al. (2013). Managerial ability is measured by comparing the sales generated by each company towards the 7 inputs used by the company (Cost of Goods Sold, Selling and Administrative Expenses, Net PP\&E, Net Operating Leases, Net Research and Development, Purchased Goodwill, and Other Intangible Assets).

$$
\max _{\mathrm{v}} \boldsymbol{\theta}=\frac{\text { Sales }}{v_{1} C o G S+v_{2} S G \mathcal{E} A+v_{3} P P E+v_{4} \text { OpsLease }+v_{5} R \mathcal{E D}+v_{6} \text { Goodwill }+v_{7} \text { OtherIntan }}
$$

The audit committee was measured by using a dummy variable (Murwaningsari, 2014). A value of 1 is given for the company that has an audit committee member with competence in accounting and 0 value for the company that does not have an audit committee member with competence in accounting. Macroeconomic factor used in this research is the interest rate. Data on average interest rates in 2014, 2015 and 2016 were seen through the official website of Bank Indonesia at http://www.bi.go.id/en/moneter/birate/data/Default.aspx. 
Control variables consist of (1) company size is measured using the natural logarithm of total assets (Wang, 2013); (2) Abnormal return is measured by the difference between the actual return and the return expectations (Jogiyanto, 2015); (3) Leverage is measured by total debt / total assets (Murwaningsari, 2014); (4) Capital structure is measured by debt-to-equity ratio which is total liabilities / total equity (Ross et al., 2013); (5) Liquidity is measured by the current ratio is current assets / current liabilities (Umobong, 2015).

\section{Research Model}

The model equation are as follows:

$1^{\text {st }}$ regression model to test hypotheses 1 and 2:

$\mathrm{EQ}=\mathrm{a}_{0}+\mathrm{a}_{1} \mathrm{MA}+\mathrm{a}_{2} \mathrm{I}+\mathrm{a}_{3} \mathrm{~S}+\mathrm{a}_{4} \mathrm{AR}+\mathrm{a}_{5} \mathrm{~L}+\mathrm{a}_{6} \mathrm{CS}+\mathrm{a}_{7} \mathrm{LQ}+\varepsilon$

$2^{\text {nd }}$ regression model to test hypotheses 3 :

$\mathrm{EQ}=\gamma_{0}+\gamma_{1} \mathrm{MA}+\gamma_{2} \mathrm{I}+\gamma_{3} \mathrm{AC}+\gamma_{4} \mathrm{AC}{ }^{*} \mathrm{MA}+\gamma_{5} \mathrm{~S}+\gamma_{6} \mathrm{AR}+\gamma_{7} \mathrm{~L}+\gamma_{8} \mathrm{CS}+\gamma_{9} \mathrm{LQ}+\varepsilon$

Note:

$\overline{\mathrm{EQ}}=$ earnings quality; $\mathrm{MA}=$ managerial ability; $\mathrm{I}=$ interest rates; $\mathrm{AC}=$ audit committee; $\mathrm{S}=$ firm size; $\mathrm{AR}$ = abnormal return; $\mathrm{L}=$ leverage; $\mathrm{CS}=$ capital structure; $\mathrm{LQ}=$ liquidity

\section{Data Analysis}

The data are analyzed using SPSS version 22. The hypothesis or significance test is done with multiple regression, namely by comparing significance (sig. or p-value) with a. If sig. or p-value is less than $\alpha$; then statistical significance is attained. The coefficient of determination (Cox-Snell $\left.R^{2}\right)$ is used to measure the ability of independent variables to predict a dependent variable.

Results and Discussions

Descriptive Statistics and Correlation Matrix

Table 1 Descriptive Statistics

\begin{tabular}{|l|r|r|}
\hline Variables & \multicolumn{1}{|c|}{ Mean } & \multicolumn{1}{|c|}{ Std. Deviation } \\
\hline Earnings Quality & 6.087696082 & 70.48976688 \\
\hline Managerial Ability (MA) & -2.204333158 & 10.55246718 \\
\hline Macro conditions (Interest I) & 0.0962 & 0.2953 \\
\hline Audit Committee (AC) & 1.333333333 & 0.472161798 \\
\hline Size (S) & 26.32558196 & 6.988461175 \\
\hline Abnormal return (AR) & 0.003917168 & 0.058831577 \\
\hline Leverage (L) & 0.70751859 & 1.43527573 \\
\hline Liquidity (LQ) & 6.676378205 & 13.05986133 \\
\hline Capital structure (CS) & 80.88184962 & 796.8385468 \\
\hline MA*AC & -3.249786608 & 20.15413786 \\
\hline
\end{tabular}

The descriptive statistics in table 1 show that the capital structure has a relatively high standard deviation value compared to the mean. This shows that sample variability for capital structure is quite high. As for managerial ability variables, abnormal return, leverage and liquidity, although the standard deviation value is higher than the mean, but the difference is relatively small. This means that sample variability for managerial capability, abnormal return, leverage and liquidity is relatively high. Audit committees and other control variables, like firm size have a standard deviation standard lower than the average value. This means that the audit committee and firm size in this research sample are homogeneous and low variability.

The data normality was tested with the Kolmogorov-Smirnov. The test results show that the asymp sig value is smaller than $\alpha=0.05 \%$ which is 0.125 . Therefore, it can be concluded that regression of residual is normally distributed. The Classical assumption tests include (i) homoscedasticity assumptions using the Glejser; (ii) no-multicollinearity assumption using VIF test; (iii) no-autocorrelation assumption 
using Durbin-Watson Test. Test results show that the data is free of autocorrelation, heteroscedasticity and multicollinearity.

Table 2 Correlation Matrix

\begin{tabular}{|c|c|c|c|c|c|c|c|c|c|}
\hline Variable & EQ & MA & I & S & AR & L & LQ & CS & AC \\
\hline EQ & 1.000 & & & & & & & & \\
\hline MA & .246 & 1.000 & & & & & & & \\
\hline$p$-value & $.001^{* * *}$ & & & & & & & & \\
\hline I & .018 & 115 & 1.000 & & & & & & \\
\hline $\mathrm{p}$-value & .412 & $.075^{*}$ & & & & & & & \\
\hline S & -.048 & -.014 & .139 & 1.000 & & & & & \\
\hline $\mathrm{p}$-value & .272 & .431 & $.040^{* *}$ & & & & & & \\
\hline AR & -.076 & .010 & -.028 & .012 & 1.000 & & & & \\
\hline $\mathrm{p}$-value & .172 & .452 & .362 & .440 & & & & & \\
\hline L & .121 & .018 & -.068 & .136 & .010 & $\begin{array}{r}1.00 \\
0\end{array}$ & & & \\
\hline $\mathrm{p}$-value & $.064^{*}$ & .410 & .197 & $.044^{* *}$ & .452 & & & & \\
\hline LQ & -.070 & -.041 & -.111 & -.066 & -.042 & -.069 & 1.000 & & \\
\hline p-value & .190 & .303 & .082 & .205 & .298 & 195 & & & \\
\hline CS & -.047 & .001 & -.050 & -.457 & -.017 & -.009 & -.057 & 1.000 & \\
\hline $\mathrm{p}$-value & .280 & .493 & .266 & $.000^{* * *}$ & .415 & . 457 & .237 & & \\
\hline $\mathrm{AC}$ & .235 & -.109 & .000 & .023 & -.059 & .101 & -.001 & -.002 & 1.000 \\
\hline P-value & $.001^{* * *}$ & .085 & .500 & .387 & .231 & .102 & .493 & .490 & \\
\hline
\end{tabular}

Note: $\mathrm{EQ}=$ earnings quality; $\mathrm{MA}=$ managerial ability; $\mathrm{I}=$ interest; $\mathrm{S}=$ size; $\mathrm{AR}=$ abnormal return; $\mathrm{L}=$

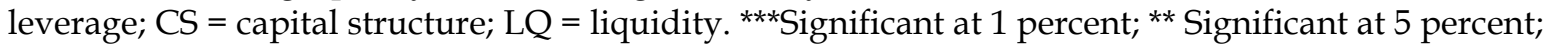
*Significant at 10 percent

Table 2 shows that the correlation between managerial skills and earnings quality as well as the correlation between audit committee and earnings quality, that has significant value $0.001<0.01$. This means that there is a positive and very significant effect between managerial skills and the earnings quality, as well as the audit committee with earnings quality. This correlation indicates that the higher the managerial skills and the competence of internal audit, the quality earnings quality will also be higher, and vice versa.

\section{The Results of Hypothesis 1 dan 2}

$$
\begin{aligned}
& E Q=a_{0}+a_{1} M A-a_{2} I+a_{3} S+a_{4} A R+a_{5} L+a_{6} C S+a_{7} L Q+\varepsilon \\
& E Q=0.08532+0.00299 M A-0.00016 I-0.00256 S-0.17790 A R+0.02390 L-0.00072 C S+0.00002 L Q+\varepsilon
\end{aligned}
$$

Table 3 shows that the effect of managerial ability on earnings quality using earnings persistence shows positive and significant results and supports hypothesis 1 . This shows that managers with higher ability to predict trends, justify and estimate accruals, eventually will be able to show a good earnings quality. This result supports Dechow and Schrand (2004); Bamber et al (2010); Ge et al (2011); DeJong and Ling (2010); Libby and Luft (1993) and Demerjian et al (2013). The opposite result is indicated by the effect of macro conditions using interest rate shows the an insignificant negative result and the result does not 
support hypothesis 2 . It shows that macro condition (interest rate) can reduce the earnings quality, but for relatively high interest rate condition as described by Charitou et al 2004. Interest rates for 3 years (20142016) with the average of $7.28 \%$

(medium interest category, http://www.bi.go.id/en/moneter/birate/data/Default.aspx). While for the control variable, only leverage is significant to earnings quality. This result supports Keshtavar et al, 2013. Simultaneously with alpha 5\%, model of influence of managerial ability, macro condition, company size, abnormal return, leverage, capital structure and liquidity to earnings quality using earnings persistence show a good model. This is indicated by the F value of 0.031 and adjusted R square valued of 0.054 .

Table 3 Empirical Results

\begin{tabular}{lcccl}
\hline Variables & Prediction & Coefficients & P Value (sig) & Hypothesis Status \\
\hline C & & 0.08532 & 0.129 & \\
MA & + & 0.00299 & $0.002^{* *}$ & Sig $^{* *}(\mathrm{H} 1$ supported $)$ \\
I & - & -0.000161 & 0.996 & $\mathrm{~ns}(\mathrm{H} 2$ not upported $)$ \\
S & + & -0.00256 & 0.208 & $\mathrm{~ns}$ \\
AR & + & -0.1779 & 0.288 & $\mathrm{~ns}$ \\
L & + & 0.0239 & $0.09^{*}$ & Sig* \\
CS & + & -0.00072 & 0.385 & $\mathrm{~ns}$ \\
LQ & - & 0.00002 & 0.242 & $\mathrm{~ns}$ \\
F-test & & $0.031^{* *}$ & \\
Adjusted Rsquare & & 0.054 & & \\
N & & 159 & & \\
\hline
\end{tabular}

Note: $\mathrm{MA}=$ managerial ability; $\mathrm{I}$ = interest rates; $\mathrm{S}$ = firm size; $\mathrm{AR}=$ abnormal return; $\mathrm{L}=$ leverage; $\mathrm{CS}=$ capital structure; LQ = liquidity; **Significant at 5\%; *Significant at $10 \%$.

\section{The Results of Hypothesis 3}

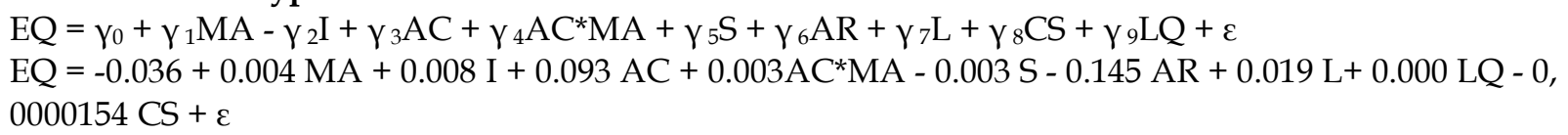

Table 4. Empirical Result

\begin{tabular}{|c|c|c|c|c|}
\hline Variables & Prediction & Coeff (B) & P Value (Sig) & Hypotheses Status \\
\hline C & & -0.036 & 0.58 & \\
\hline MA & + & 0.004 & $0.000^{* * *}$ & $\operatorname{Sig}^{* * *}(\mathrm{H} 1$ supported $)$ \\
\hline I & - & 0.008 & 0.852 & ns (H2 not supported) \\
\hline$S$ & + & -0.003 & 0.199 & ns \\
\hline AR & + & -0.145 & 0.372 & $\mathrm{~ns}$ \\
\hline $\mathrm{L}$ & + & 0.019 & 0.192 & ns \\
\hline LQ & - & 0 & 0.366 & ns \\
\hline CS & + & $-1.54 \mathrm{E}-05$ & 0.231 & $\mathrm{~ns}$ \\
\hline AC & + & 0.093 & $0.001^{* * *}$ & $\operatorname{sig}^{* * *}$ \\
\hline $\mathrm{MA}^{*} \mathrm{AC}$ & + & 0.003 & $0.007^{* * *}$ & sig*** (H3 supported) $^{*}$ \\
\hline F-Test & & & $0.001^{* * *}$ & \\
\hline \multicolumn{2}{|c|}{ Adjusted R Square } & 0.112 & & \\
\hline
\end{tabular}


Note: $\mathrm{MA}=$ managerial ability; $\mathrm{I}=$ interest rates; $\mathrm{AC}=$ audit committee; $\mathrm{S}=$ firm size; $\mathrm{AR}=$ abnormal return; $\mathrm{L}=$ leverage; $\mathrm{CS}=$ capital structure; $\mathrm{LQ}=$ liquidity; ***Significant at $1 \%$

Table 4 shows that the interaction between managerial ability and audit committee has a positive and significant interaction (Hypothesis 3 is supported). This means that the audit committee strengthens the effect of managerial ability towards earnings quality. These results support Dechow et al 1995 which explains that the internal structure of the firm is a factor that can limit the chance of managers in doing earnings manipulation. Simultaneously with alpha 1\%, model of influence of managerial ability, macro condition, audit committee, interaction managerial ability and audit committee, firm size, abnormal return, leverage, capital structure and liquidity to earnings quality show a good model. This is indicated by the $F$ value of 0.001 and adjusted $R$ square value of 0.112 .

\section{Conclusions, Implications, Limitations and Future Research Conclusions and Implications}

It was concluded that the managerial ability has a positive and significant effect towards earnings quality. Macroeconomic conditions with interest rate has a negative and significant effect towards earnings quality. The audit committee can strengthen the effect of managerial ability towards earnings quality.

With findings that managerial skills has a positive and significant effect towards earnings quality, therefore the result of this research can answer the opposition earlier about managerial skills towards earnings quality. These results support Dechow and Schrand (2004); Bamber et al (2010); Ge et al (2011); DeJong and Ling (2010); Libby and Luft (1993) and Demerjian et al (2013), which stated that the earnings quality is reflected by the performance of the company and the main actors on the company's operations is the manager. This result is contrary to what was stated by Healy $(1985,1996)$ and Houlthausen et al (1995), that managerial skills that are closely related to earnings management practices which could decrease the earnings quality. Besides answering the contrary results of previous research, this research has also answered many questions related to how to create a high earnings quality, the environment that can create earnings quality, or factors that can create earnings quality. This research enriches the results of previous research related to factors that affect the earnings quality such as the manipulation of accounting in the form of accrual accounting and real activity that deviates from normal practice (Lara, 2009); ownership of private companies and public (Givoly et al, 2010; Katz, 2009); earnings management (Prior et al, 2008); companies that consistently outperform their industry rivals and the strength of corporate governance (Sivaramakrishnan and Yu, 2008).

The findings that are related to macro conditions which is proxied by the interest rate is that the macro condition has a significant negative effect towards earnings quality. This is likely due to the interest rate on the period of data collection (2014-2016) includes in the category of interest is relatively proxied by the persistence of earnings 7.28\% (interest rate category, http://www.bi.go.id/en/ monetary / Pirate / data / default.aspx).

Another finding is the audit committee can strengthen the effect of the managerial skills and the earnings quality. These findings strengthen the opinion of Doyle et al, 2007; Ashbaugh-Skaife et al, 2008 and Becker et al, 1998, which stated that the earnings quality is also associated with the company's infrastructure. Company infrastructure examined in this research is the ability of the internal control proxied by the audit committee. These results support Baroko et al, 2017 and Murwaningsari, 2014, the audit committee can improve the quality of the company's financial information. Other findings related to the variable control is that leverage has a significant effect towards earnings quality. This may be due to the high level of leverage can provide a strong incentive to managers to manage earnings. These results support Keshtavar et al, 2013.

The results of this research contribute to the theoretical implications related to agency theory (Jensen and Meckling, 1976). The results of managerial ability that has a positive effect towards the earnings quality as well as the objection to the assumptions of agency theory is that managers tend to pursue a personal goal of maximizing shareholder interests. This research also contributes to the literature related to earnings quality, namely that the managerial ability can be an important factor in improving earnings quality, and internal control using audit committee strengthen the effect of managerial ability 
towards earnings quality. The research also has implications for owners and management, which provide input that capable managers with the audit committee can increase the earnings quality.

\section{Limitations and Future Research}

This research only used sample of manufacturing firms, so that the results cannot be generalized. This research also only used the audit committee as a proxy for the ability of internal control, so that the result is less comprehensive. Limited number of control variables used in the study is likely to affect the results of the research. Suggestions for future research is to expand the sample to include not only the manufacturing companies, extend the period of data collection as well as include other variables related to the ability of internal control, such as independent commissionaire and internal auditors capability also suggested in future research, and also to use another proxy of earnings quality, for example, feedback value, timeliness etc. Another proxy for macroeconomic conditions that can be considered is the level of inflation. Additional control variables to minimize bias is also recommended to be done in future research.

\section{References}

Aier, J., J. Comprix, M. Gunlock, and D. Lee. 2005. The financial expertise of CFOs and accounting restatements. Accounting Horizons 19 (3): 123-135.

Amihud, Yakov. 2008. Liquidity, the value of the firm, and corporate finance. Journal in the Summer 2 (20): 1-40.

Arens and Loebbecke. 2008. Auditing an integrated approach. USA: Prentice. Hall

Ashbaugh-Skaife, H., D. Collins, W. Kinney, and R. LaFond. 2008. Internal control deficiencies, remediation and accrual quality. The Accounting Review 83 (1): 217-250.

Bapepam No.Kep 29/PM/2004. Tentang pembentukan dan pedoman pelaksanaan kerja komite audit.

Babatunde and Olaniran. 2015. Ownership structure and performance of entrepreneurial firms in Nigeria. International journal of economics and business management 1 (3):1-12.

Barako, G., Phil H. dan H.Y Izan. (2007). Factors Influencing Voluntary Corporate Disclosure by Kenyan Companies. International Review 14 (2): 107-125.

Bamber, L., J. Jiang, and I. Wang. 2010. What's my style? The influence of top managers on voluntary corporate financial disclosure. The Accounting Review 85 (4): 1131-1162.

Becker, C., M. DeFond, J. Jiambalvo, and K. R. Subramanyam. 1998. The effect of audit quality on earnings management. Contemporary Accounting Research 15 (1): 1-24.

Brigham, F.E dan Houston, F.J. 2006. Intermediate Financial Management. 10 $0^{\text {th }}$ edition. Erlangga, Jakarta.

Copeland T.E dan J.F.Weston. 1992. Financial theory and corporate policy, $3^{\text {rd }}$ edition. Addison-Wesley Publishing Company.

Charitou, A., E. Neophytou, and C. Charalambous. 2004. Predicting corporate failure. Empirical evidence for the UK. European. Accounting Review 13 (3): 465-497.

Dechow, P. 1994. Accounting earnings and cash flows as measures of firm performance: The role of accounting accruals. Journal of Accounting and Economics 18 (1): 3-42.

Dechow, P., and C. Schrand. 2004. Earnings Quality. Charlottesville, VA: The Research Foundation of CFA Institute.

Dechow, P., and I. Dichev. 2002. The quality of accruals and earnings: The role of accrual estimation errors. The Accounting Review 77 (4): 35-59.

Dechow, P. M., R.G. Sloan and A.P. Sweeney. 1995. Detecting earnings management. The Accounting Review 70 (2):193-225.

DeFond, M.L. 2010. Earnings quality research: Advances, challenges and future research. Journal of Accounting and Economics 50 (2-3), 402-409.

DeJong, D., and Z. Ling. 2010. Managers: Their Effects on Accruals and Firm Policies. Working paper The University of Iowa.

Demerjian, P., B. Lev, and S. McVay. 2006. Managerial ability and accruals quality. Working paper. Stem school of business.

Demerjian, P., B. Lev, and S. McVay. 2012. Quantifying managerial ability: A new measure and validity tests. Management Science 58 (7): 1229-1248. 
Demerjian, P., B. Lev, and S. McVay. 2013. Managerial ability and earnings quality. The Accounting Review 88 (2): 463-498.

Doyle, J., W. Ge, and S. McVay. 2007. Accruals quality and internal control over financial reporting. The Accounting Review 82 (5): 1141-1170.

Francis, J., A. Huang, S. Rajgopal, and A. Zang. 2008. CEO reputation and earnings quality. Contemporary Accounting Research 25 (1): 109-147.

Francis, J., R. LaFond, P. Olsson, and K. Schipper. 2004. Costs of equity and earnings attributes. The Accounting Review 79 (4): 967-1010.

Ge, W., D. Matsumoto, and J. Zhang. 2011. Do CFOs have style? An empirical investigation of the effect of individual CFOs on accounting practices. Contemporary Accounting Research 28 (4): 1141-1179.

Healy, P. 1985. The effect of bonus schemes on accounting decisions. Journal of Accounting and Economics 7: 85-107.

Healy, P. 1996. Discussions of a market based evaluation of discretionary accrual models. Journal of Accounting Research 34: 107-115.

Healy, P and Wahlen, J.M. 1999. A Review of the Earnings Management Literature and Its Implications for Standard Setting. Accounting Horizons 13(4): 365-383.

Houlthausen, R.,D.Lacker, dan R.G.Sloan. 1995. Annual bonus schemes and manipulation of earning, Additional evidence on bonus plan and income management. Journal of Accounting and Economics 29-74.

http://www.bi.go.id/id/moneter/inflasi/data/Default.aspx. Retrieved on 10 June 2017.

http://www.bi.go.id/en/moneter/bi-rate/data/Default.aspx. Retrieved on 10 June 2017.

Gharezi, Davood and Zadeh, Mohammad Reza Abbas. 2013. The relationship between earnings quality and risk of liquidity in Tehran Stock Exchange. Interdisciplinary Journal of Contemporary Research in Business 5 (3): 782-805.

Givoly D., Hayn CK., Katz SP. 2010. Does public ownership of equity improve earnings quality? The Accounting Review: 85(1): 195-225.

Jensen M.C., and Meckling W.H. 1976. Theory of the firm: Managerial behavior, agency costs and ownership structure. Journal of financial economics, 3 (4): 305-360

Jogiyanto, H. 2015. Teori Portfolio dan Analisis Investasi. Edisi 10. Yogyakarta: BPFE.

Katz, S P. 2009. Earnings quality and ownership structure: The role of private equity sponsors, The accounting review 84 (3): 623-658.

Keshtavar, Ali; Moeinaddin, Mahmoud; Dehnavi, Hasan Dehghan. 2013. Need for capital management and capital structure in the world today. International Journal of Modern Management Sciences 2 (2): 67-74.

LaFond. R. 2008. Discussion of: CEO reputation and earnings quality. Contemporary Accounting Research 25 (1): 149-156.

Lara., Garcia, J.M., Osma., Garcia, B., Neophytou,E. 2009. Earnings quality in expost failed firms. Accounting and business research 39 (2): 119-138.

Libby, R., and J. Luft. 1993. Determinants of judgment performance in accounting settings: Ability, knowledge, motivation and environment. Accounting, Organization and Society 18 (5): 425-450.

Machdar, N.M., Manurung, A.H., and Murwaningsari, E. 2017. The effects of earnings quality, conservatism, and real earnings management on the company's performance and information asymmetry as a moderating variable. International Journal of Economics and Financial Issues 7 (2): 309318.

Modigliani, Franco, and Miller, Merton H. 1958. The cost of capital, corporate finance, and the theory of investment. American Economic Review 48 (3): 261-280.

Murwaningsari, E. 2014. The influence of intellectual capital towards firm value with independent commissioner and audit committee as moderating variable. International Journal of Engineering, Business and Enterprise Application (IJEBEA) 7 (2): 6-11.

Prior, D., Surroca, J., Tribo, J.A. 2008. Are socially responsible managers really ethical? Exploring the relationship between earnings management and corporate social responsibility, Journal compilation 16 (3): 160-177. 
Pereira Garmendia, Diego Walter, Inflation, Real Stock Prices and Earnings: Friedman Was Right. 2010. Available at SSRN: https:/ / ssrn.com/abstract=1802431 or http:/ /dx.doi.org/10.2139/ssrn.1802431

Ross, S., Westereld, R., Jafe, J. 2013. Corporate Finance. 10 $0^{\text {th }}$ ed. New York: The McGraw-Hill Companies, Inc.

Sivaramakrishnan, K., 2008. On the association between corporate governance and earnings quality. AAA Financial Accounting and Reporting Section (FARS) Paper 1:36

Umobong, A. 2015. Assessing the impact of liquidity and profitability ratios on growth of profits in pharmaceutical firms in Nigeria. European Journal of Accounting, Auditing and Finance Research 3 (10): 97-114.

Velury U. 1999, The effect of institutional ownership on the quality of earnings. Submitted in partial fulfillment of the requirements for the degree of doctor of philosophy in The Darla Moore School of Business Univer-sity of South Carolina, Umi Microfon 9928350. Copyright 1999, Umi Company.

Velury U., and Jenkins, D.S. 2006. Institutional ownership and the quality of earnings. Journal of business research 59 (9), 1043-1051.

Wang, J.L. 2013. Accounting conservatism and information asymmetry: Evidence from Taiwan. International business research 6 (7), 32-43. 